\title{
Wine and health: A review of its benefits to human health
}

\author{
D.A. Wurz \\ Federal Institute of Santa Catarina, Av. Expedicionários, 2150, CEP 89460-000, Canoinhas, SC, Brazil
}

\begin{abstract}
Modern society seeks to consume foods that can treat and prevent disease, as well as increase longevity, and in this context stand out functional foods rich in antioxidant compounds with proven health benefits, as well as beverages that bring benefits to the health and are widely used by the population, such as wine. Wine has always been linked in some way to the history of man, either because it is a beverage with its own flavor and personality or because of the health benefits it brings. Studies carried out throughout the world show that wine, taken in a moderate amount, contributes to the health of the human organism, increasing the quality and the life time, being the polyphenols the main compounds present in the wine responsible for this contribution. In this context, the objective of this study is to carry out a bibliographical review on the main researches and studies carried out with the theme wine and health, with emphasis on the beneficial effect of the phenolic composition of red wines, and thus contribute to the dissemination of the benefits of regular consumption and wine to human health.
\end{abstract}

\section{Introduction}

Wine is a beverage from the alcoholic fermentation of ripe and fresh grapes or fresh grape juice. As a biochemical definition would be: drink from the alcoholic fermentation of grape juice sugars by yeast. Wine has always been linked in some way to the history of man, either because it is a beverage with its own flavor and personality or because of the benefits it brings to health. Important ancient civilizations, like the Egyptians, the Greeks and the Romans, besides the Hindus, used wine as medicine for the body and for the soul. Historical records show that the medicinal use of wine by man has been a practice made for over 2000 years [1].

In general, we can mention as benefits of wine: prevention of heart and circulatory diseases; if drink together with the meal is the most beneficial for diabetics; favorable to the fight against obesity; provides greater longevity and quality of life; creates barriers to the development of dementia; the meal accompanied by wine results in a better digestion; anti-infective effect; beneficial effects on women's health; are excellent for the skin; can prevent blindness; have anti-inflammatory action; can alleviate lung diseases; besides being a very pleasant drink [2].

Wine is one of the oldest beverages, has always been related to the history of man and presents benefits to human health [3]. Although there have been reports of wine consumption for more than 7,000 years, the benefits of wine were only highlighted in 1992, when the French Paradox was published [4]. What arouses scientific attention is related to the eating habits adopted by the French, who, despite having high levels of sedentary lifestyle, smoking, high consumption of saturated fats and higher cholesterol levels, when compared with other industrialized countries, have a lower incidence of diseases coronary diseases, a fact attributed to the high consumption of wine [5]. Data presented by the World Health Organization (WHO) show that the mortality rates due to cardiovascular diseases in France are smaller when compared to other countries, which is why the name of the French Paradox has appeared [6].

In this context it is possible to associate wine consumption with health benefits associated with healthy eating and quality of life, but this only happens if it is consumed in a certain quantity [7].

In this context, the objective of this study is to carry out a bibliographical review on the main researches and studies carried out with the theme wine and health, with emphasis on the beneficial effect of the phenolic composition of red wines, and thus contribute to the dissemination of the benefits of regular consumption and wine to human health.

\section{Materials and methods}

The study is based on a literature review and research results from institutions that work in this area.

For the development of the work, scientific works were compiled, referring to national and international publications related to the theme "Wine and Health" and "Wine: functional food", "Resveratrol", which were consulted through periodicals indexed in the Scielo portal, as well as data collection in official institutions, such as UVIBRA (Brazilian Union of Viticulture).

Each work was cataloged and the data were organized in such a way that it was possible to elaborate the present work.

\section{Results and discussion}

The medicinal use of wine was widely employed by the Greeks. Hippocrates (460-370 BC) reported on the therapeutic properties of wine, a beverage used as a dietary supplement in cachexia, diuretic, purgative, antipyretic, 
antiseptic, in plasters and also against depression during convalescence [8]. The main constituents of wine salts are the mineral anions, sulfate, phosphate, chloride and sulfite, and organic, tartrate, malate and lactate, as well as some cations such as $\mathrm{K}+, \mathrm{Na}+, \mathrm{Mg} 2+, \mathrm{Ca} 2+, \mathrm{Fe} 2+, \mathrm{Al} 2+$ and $\mathrm{Cu} 2+[9]$. Calcium and iron salts are used in medicine for the treatment of descaling and anemia [10].

The richness of the elements that make it make it, in fact, a true liquid food of incomparable virtues and the main condition for wine to bring health benefits is that it be taken moderately and together with meals, absorption of the nutrients that are contained in food [11].

Studies conducted worldwide prove that wine taken in moderate amounts contributes to the health of the human body [12]. It is suggested that resveratrol may be one of the constituents of the wine conferring this protection [13]. Resveratrol acts in the prevention of heart disease, associated with the consumption of red wine, as well as inhibition of platelet aggregation, alteration in eucosanoid synthesis and by modulating lipid and lipoprotein metabolism [14].

The most abundant sources of resveratrol are the grapes Vitis vinifera, V. labrusca, V. muscadine which are normally employed in the manufacture of wine. Resveratrol is found in vines, roots, seeds and stalks, but the highest concentration is in the film of grapes containing 50 to $100 \mathrm{xg} / \mathrm{g}$ [7]. The concentrations of resveratrol found in different wine types vary depending on the infection with Botrytis cinerea, grape cultivar, geographical origin, wine type and oenological practices [15].

Its antioxidant capacity is related to the prevention of cardiovascular diseases [16], anticancer and antiinflammatory properties [17]. Resveratrol can inhibit the initiation, promotion and progression of tumors [18], reduction of cell death by oxidative stress [19], inhibition of oxidation of low density human lipoprotein (LDL) [20,21], inhibition of platelet aggregation, impairment of anti-inflammatory activity [22] and reduced effects of some neurological diseases such as Alzheimer's [23].

The concentration of resveratrol is a response of the plant to an aggressor agent and is influenced by the presence of pathogenic microorganisms [24]. The cardioprotective effect of wine can be attributed to resveratrol. It induces protection against reperfusion injury after ischemia (R/I), has been documented in the heart, kidney and brain. Resveratrol has high power to sequester oxygen free radicals and increase nitric oxide production.

In Brazilian wines, Vanderlinde et al. [25] found higher values of resveratrol in relation to Argentine, Chilean and Uruguayan wines. Grapes grown in hot, dry climates that are less affected by the fungus have lower concentrations of resveratrol, whereas in cold and humid climates they have higher concentrations [14]. Rosier et al. [26], quantified resveratrol content in red and white wines, Brazilian, Argentine and Chilean wines. The wines presented an average of $2.33 \mathrm{mg} \mathrm{L}^{-1}$ for reds and $0.091 \mathrm{mg} \mathrm{L}^{-1}$ for whites, respectively. In relation to the varieties, the highest levels were observed for Merlot with an average of $3,580 \mathrm{mg} \mathrm{L}^{-1}$ and the highest concentration was found in a Brazilian red wine, with $8,247 \mathrm{mg} \mathrm{L}^{-1}$.

The phenolic compounds present in products derived from grapes, Vitis vinifera L., such as grape juice and wines, especially red wine, have antioxidant activity that combats free radicals. Studies aimed at evaluating antioxidant activity and quantifying phenolic compounds, have proven that red wine had higher phenolic compounds contents and better antioxidant activity. For Europeans, wine is considered a food supplement, as it contains carbohydrates, vitamins and minerals, from the grape. In addition to water ( 80 to $85 \%$ of the volume), the drink still provides the body with energy in the form of sugars such as glucose and fructose. Minerals include potassium, copper, zinc, fluorine, magnesium, aluminum, iodine, boron and silicon which, even in small quantities, are indispensable for the body to perform well all its functions [27].

Like any alcoholic beverage, wine also causes problems, when ingested, beyond limits. In $100 \mathrm{ml}$ (half a cup) there are 8 to $10 \mathrm{~g}$ of ethanol. Therefore, those who take excessive amounts of wine (more than half a liter), regardless of their quality, are subject to the unpleasant effects of ethanolic intoxication the next day. Among other harmful effects, such as dehydration of the organism, alcohol, when absorbed, rapidly falls into the circulatory chain, causing peripheral vasodilation, responsible for headache. There is no fixed rule to say what a person's limit is in relation to alcohol. This will depend on some factors, such as age, sex and emotional state, in addition to the fact that each has its own level of tolerance to alcohol, that is, each organism responds differently to alcohol [28].

\section{Conclusion}

A series of studies prove the benefits of regular and moderate consumption of red wine to human health, mainly relating to its phenolic composition. Since ancient times, wine has been closely linked to the evolution of medicine, and the consumption of red wine is now recognized as beneficial to health by medicine.

The components of red wine are known as potent antioxidants and have been identified as having anticarcinogenic, anti-inflammatory and antimicrobial properties.

The components present in wines show that wine can be considered a functional food.

\section{References}

[1] H. Johnson, Vintage: The Story of Wine (1989)

[2] J.M. Filho. Vinho é Saúde! Vinho\&Cia (2014), p. 151

[3] N.G. Penna, L.H.R. Hecktheuer, Informa 16, 64 (2004)

[4] E.M.P. Facco, Ciência e tecnologia Alimentar 27, 874 (2007)

[5] B. Fuhrman, N. Volkova, R. Coleman, M. Aviram, J. Nutr. 135, 722 (2005)

[6] G.G. Souza, L.O. Meneghin, S.P. Coelho, J.F. Maia, A.G. Silva, Natureza on-line 4, 80 (2006)

[7] G. Comachio, L.R. Toledo, O Vinho Tinto Como Alimento Funcional: Uma Revisão da Literatura Sobre a Quantidade Recomendada (2011)

[8] R. Corder, A Dieta do Vinho (Rio de Janeiro, Sextante, 2008)

[9] E. Vogt, El vino: Obtencion, Elaboracion y Analisis, 2nd edn. (Zaragoza: Acribia, 1986)

[10] P. Ribéreau-Gayon, Handbook of Enology: The Chemistry of Wine Stabilization and Treatments, 2nd edn. (John Wiley \& Sons, England, 2006)

[11] UVIBRA - União Brasileira de Vitivinicultura, Vinho e Saúde (UVIBRA, Bento Gonçalves, 2015) 
[12] J.F. Tomera, Trends Food Sci. Technol. 10, 129 (1999)

[13] M. Adrian, A.C. Jeandet, D. Breuil, S. Levite, S. Debord, R. Bessis, Amer. J. Viticulture Enol. 51, 37 (2000)

[14] G.J. Soleas, E.P. Diamands, D.M. Goldberg, Clin. Biochem. 30, 91 (1997)

[15] R.M. Lamuela-Raventos, P. Romero, J. Agric. Food Chem. 43, 281 (1995)

[16] W.R. Leifert, W.Y. Abeywardena, Nutr. Res. 28, 729 (2008)

[17] B. Delaunois, S. Cordelier, A. Conreux, C. Clement, P. Jeandet, Plant Biotechnol. J. 7, 2 (2008)

[18] Y. Bader, N. Getoff, Antincancer Res. 26, 4403 (2006)

[19] Y. Bader, R.M. Quint, N. Getoff, Radiation Phys. Chem. 7, 708 (2008)

[20] H. Berrougui, G. Grenier, S. Loued, G. Drouin, A. Khalil, Atherosclerosis 7, 420 (2009)
[21] V.R. Ramprasath, P.J.H. Jones, Eur. J. Clin. Nutr. 64, $660(2010)$

[22] J. Martinez, J.J. Moreno, Biochem. Pharmacol. 59, 865 (2000)

[23] F. Zhang, J. Liu, J.S. Shi, Eur. J. Pharmacol. 636, 1 (2010)

[24] J. Triska, M. Houska, Czech J. Food Sci. 30, 489 (2012)

[25] R. Vanderlinde, F.R. Spinelli, S. Leonardelli, G.J. Carnielli, S.V. Dutra, Revista Brasileira de Viticultura e Enologia 7, 76 (2015)

[26] J.P. Rosier, M. Carneiro, R. Miotto. Teores de resveratrol em vinhos sul americanos, In Congresso Brasileiro de Viticultura e Enologia (Bento Gonçalves, Anais Eletrônicos, Bento Gonçalves, 2003)

[27] C.E. Daudt, N.G. Penna, Ciência e Tecnologia de Alimentos 7, 72 (1987)

[28] J.B. German, R.L. Walzem, Annual Rev. Nutr. 20, $561(2000)$ 